\title{
Nutrient digestibility and blood parameters of West African dwarf sheep fed
} sugarcane top silage

*1 Akinbode, R. M., Isah, O. A., ' Oni, A. O., ${ }^{1}$ Adebayo, K. O., ${ }^{1}$ Aderinboye, R. Y.,

${ }^{1}$ Adelusi, O. O. and ${ }^{2} \mathrm{Ojo}$, V. O. A.

${ }^{I}$ Department of Animal Nutrition,

${ }^{2}$ Department of Pasture and Range Management,

Federal University of Agriculture, Abeokuta, Ogun State, Nigeria.

*Corresponding author: rmakinbode@yahoo.com; 08038365288

Abstract

Nutritive value of low quality crop residues is improved with addition of protein-rich byproducts (poultry litter) or chemical compounds (urea) and can serve as feed resource to ruminant during the dry season. This study investigated the nutrient digestibility and blood parameters of West African dwarf (WAD) sheep fed sugarcane top silage. Sugarcane tops were ensiled alone (control) or with $2 \%$ urea (USCT silage), $45 \%$ boiler litter (BLSCT silage) and $1 \%$ urea plus $22.5 \%$ broiler litter (UBLSCT) for 42 days. Each silage treatment contains $2 \%$ molasses. Twenty-four female West African dwarf sheep of 6-8 months of age, weighing $14.58 \pm 1.16 \mathrm{~kg}$ were randomly assigned to the four silage treatments of six animals each in a completely randomised design for 84 days. Chemical composition of the silages was determined. Performance characteristics, apparent nutrient digestibility and blood parameters of the WAD sheep were evaluated. All data were subjected to one way Analysis of Variance. Results showed that animals fed BLSCT had significantly highest $(P<0.05)$ total dry matter intake $\left(64.26 \mathrm{~g} / \mathrm{kg} \mathrm{W}^{0.75}\right)$ and daily weight gain (46.03 g/day) followed by those on UBLSCT and USCT while animals fed control diet recorded the least with highest feed conversion ratio (20.62). Digestibility of all nutrients was highest $(P<0.05)$ in sheep fed BLSCT $(71.43 \%, 71.16 \%, 75.66 \%, 64.35 \%$ and $56.82 \%$ for dry matter, organic matter, crude protein, NDF and ADF digestibility respectively) and lowest $(55.71 \%, 57.31 \%, 59.98 \%$, $39.47 \%$ and $46.92 \%$ for dry matter, organic matter, crude protein, NDF and ADF digestibility respectively ) in those on control diet. Similarly, sheep fed BLSCT recorded significant highest $(P<0.05)$ packed cell volume $(32.17 \%)$, haemoglobin $(10.82 \mathrm{~g} / \mathrm{dL})$ and red blood cell $\left(13.43 \times 10^{12} / L\right)$. The serum glucose, total protein, albumin, globulin and blood urea concentration were similar $(P>0.05)$ but higher in animals fed BLSCT $(3.94 \mathrm{mmol} / \mathrm{L}, 71.80$ $\mathrm{g} / \mathrm{L}, 37.00 \mathrm{~g} / \mathrm{L}, 34.80 \mathrm{~g} / \mathrm{L}$ and $130.55 \mathrm{mg} / \mathrm{L}$, respectively) $U S C T(3.83 \mathrm{mmol} / \mathrm{L}, 71.50 \mathrm{~g} / \mathrm{L}, 35.0$ $\mathrm{g} / \mathrm{L}, 36.50 \mathrm{~g} / \mathrm{L}$ and $140.65 \mathrm{mg} / \mathrm{L}$ respectively) and UBLSCT $(3.75 \mathrm{mmol} / \mathrm{L}, 71.20 \mathrm{~g} / \mathrm{L}$, $34.50 \mathrm{~g} / \mathrm{L}, 36.70 \mathrm{~g} / \mathrm{L}$ and $120.90 \mathrm{mg} / \mathrm{L}$, respectively) compared to control. The study concluded that SCT treated with urea or broiler litter or their combination (UBLSCT) ensiled for 42 days could be fed to ruminant during long dry season without any detrimental effect on the health of the animals.

Keywords: sugarcane top; broiler litter; urea; blood; digestibility

Introduction

Ruminant livestock farmers in Nigeria are usually faced with problems of feed shortage for their animals especially during the dry season when there is reduction in the quality and quantity of natural pasture. Convectional feeds such as concentrate which can be fed to ruminant are expensive and are in erratic supply (Akinmutimi,
2004) therefore, livestock owners are forced to migrate with their herds in search of feed and water with consequent body weight loss due to long distance trekking. This results into reduction in both productive and reproductive capacities of the animals (FAO, 1983). It also results in communal clash between livestock owners and crop farmers. However, there are 
several alternative feed resources for ruminants which are locally available, cheap and less useful to humans. These include crop residues, agro-industrial byproducts, animal waste and other forms of fibre, protein and energy. Sugarcane top is one of the crop residues derived after harvesting of the cane and is readily accepted by ruminant either fresh, dried or ensiled (Bhatti and Khan, 1996). However, due to low protein, poor mineral contents and low digestibility of nutrients (Joshi et al., 1995; Patil et al., 1999), sugarcane top is being used partially as roughage. Therefore, there is a need to upgrade the nutrient contents of sugarcane top especially protein for better utilization by ruminants since rumen micro-organisms depend on dietary protein for proper growth and optimum activity. Judicious treatment of sugarcane top with nitrogen-rich locally available resources such as urea and poultry litter can improve its nutritive value with subsequent improvement in animal performance.

Poultry litter is an agricultural waste from poultry farms which constitute health hazard due to inadequate means of disposal and it can supply between $30-90 \%$ of total protein requirement for ruminant (Shah and Muller, 1983). The major problem of offering poultry litter to ruminant is the presence of pathogenic organisms but it had been shown that autoclaving, fumigation and ensiling among other methods can render poultry litter free of pathogens (Kim et al., 2000). Urea is commonly used as feed additive to improve crude protein content, digestibility, nitrogen retention and rumen fermentation in ruminant (Fang et al., 2012). This study was therefore designed to evaluate the performance and blood parameters of West African dwarf sheep fed urea and broiler litter treated sugarcane top silage.

\section{Materials and methods Experimental site and preparation of sugarcane top for silage}

The experiment was carried out at the University Farm of the Federal University of Agriculture, Abeokuta, Ogun State, Nigeria. The sugarcane top was collected fresh immediately after harvesting at Papalanto (an area known for sugarcane production) in Ewekoro Local Government Area of Ogun State. The tops (including the leaves and the immature canes) were allowed to wilt overnight by spreading it in a well-ventilated shed, chopped into small pieces (about $2-4 \mathrm{~cm}$ ) for ease of compaction and consolidation at ensiling. The broiler litter used for this study was collected from Poultry Unit of the University Farm. Collected broiler litter was sun-dried on a concrete floor for 7 days to about $11 \%$ moisture, crushed and milled to ensure thorough mixing of the litter components. Samples of sugarcane top and broiler litter were taken and analysed for chemical composition. In addition, fertilizer grade urea (46\% nitrogen) was purchased at Agro-services Corporation, Abeokuta, Ogun State.

Chopped sugarcane tops were ensiled alone (control) or with $2 \%$ urea (USCT silage), $45 \%$ broiler litter (BLSCT silage) and 1\% urea plus $22.5 \%$ broiler litter (UBLSCT silage). Each silage treatment contains $2 \%$ molasses and was prepared weekly for 12 weeks using a total of 48 well labelled plastic containers (12 containers for each treatment) with capacity to contain $150 \mathrm{~kg}$ fresh materials each. The materials for each treatment were thoroughly mixed separately on a clean concrete floor and were firmly packed and compacted in their respective plastic containers already lined with two inserted black polythene bags. Each layer of the ensiling materials was compacted by standing on it to displace the 
air until the containers were filled. The bags were tightly tied; about $40 \mathrm{~kg}$ sand bags were placed on each silage bag and the containers were covered tightly and stored under a shed for a period of 42 days.

Management of experimental animals and design

Twenty-four female West African dwarf sheep of 6-8 months of age weighing $14.58 \pm 1.16 \mathrm{~kg}$ were used for this experiment. The animals were randomly assigned to four experimental dietary treatments of six animals per treatment in a completely randomised design. Prior to the commencement of the experiment, the animals were de-wormed with Albendazole $^{R} 2.5 \%$ body weight oral suspension (Anthelmintics) at $1 \mathrm{~mL} / 10 \mathrm{~kg}$ body weight and were treated against ectoparasite with Cypermethrin ${ }^{\circledR}$. The animals were housed individually in a well disinfected and ventilated pen. A 14-day dietary adaptation period was observed. Animals were weighed at the start of the experiment and on weekly basis till the end of the trial to determine the total weight changes. During the experiment, each animal was offered their respective silage on ad-libtum basis at 7.00 am in the morning and concentrates feed (at $1.5 \%$ body weight) as supplement at $4.00 \mathrm{pm}$. The remnants were weighed and discarded the following morning to determine the daily intake. Fresh clean water was also provided. The experiment lasted for 84 days.

\section{Digestibility study}

The digestibility study was carried out for 21 days. This was done by total faecal and urine collection method. Three animals per treatment were weighed and transferred into individual metabolic cages specially made for separate collection of faeces and urine. Each animal was offered their respective silage and concentrate daily and fresh clean water was also provided. During the last seven days of the trial, faeces voided per animal per day were collected, weighed and $10 \%$ aliquot of each day's collection of faeces from each animal was taken to the laboratory, oven dried at $65^{\circ} \mathrm{C}$ for dry matter determination. The oven-dried faeces were later bulked, milled and stored in an air-tight container pending the chemical analysis. Urine was collected from each animal per day into bottles with 2 drops of $10 \% \mathrm{H}_{2} \mathrm{SO}_{4}$ to avoid ammonia losses and was frozen at $-20^{\circ} \mathrm{C}$ pending subsequent chemical analysis.

Blood sample collection for haematology and biochemical study

At the end of the feeding trial, two sets of blood samples were taken from individual animal using $5 \mathrm{~mL}$ hypothermic syringe with needle before feeding in the morning via the jugular vein. $5 \mathrm{~mL}$ of blood was introduced into well labelled sterile bottles containing ethylene diamine tetra acetic acid (EDTA) as anticoagulant for haematological parameters. Blood samples for serum analysis were introduced into bottles that were anticoagulant free and were centrifuged at $4000 \mathrm{rpm}$ for 20 minutes after which the blood sera were separated and preserved in clean and sterile bottles at $-18^{\circ} \mathrm{C}$ for subsequent biochemical analysis.

\section{Chemical analysis}

The oven dried faecal sample was made to pass through $1 \mathrm{~mm}$ screen and was analysed for crude protein, crude fibre, ether extract and ash content (AOAC, 2005). Neutral Detergent Fibre (NDF), Acid Detergent Fibre (ADF) and Acid Detergent Lignin (ADL) were determined (Van Soest et al., 1991). Cellulose and hemicellulose were determined by calculation. Packed cell volume and haemoglobin concentration were done using the method of Dacie and Lewis (2001). Red Blood Cell (RBC), White Blood Cell (WBC) and WBC differential were determined using the Neubauer haemocytometer after appropriate dilution. Mean corpuscular 


\section{Nutrient digestibility and blood parameters of West African dwarf sheep fed sugarcane top silage}

haemoglobin concentration, mean corpuscular haemoglobin and mean corpuscular volume were calculated from RBC value as described by Jain (1993).

Serum total protein, glucose and albumin determination followed the procedures of Wermer et al. (1970), serum urea nitrogen and creatinine by modifying the method of Valley et al. (1980). Serum globulin was calculated by subtracting the albumin value from corresponding total serum protein value.

\section{Statistical analysis}

Data collected were subjected to one way Analysis of Variance (ANOVA) while significant differences among means were compared using Duncan's Multiple Range test (SAS, 1999). Data were analysed using the model; $Y_{i j}=\mu+T_{i}+{ }_{i j}$. Where $Y_{i j}$ is the observed value of the dependent variables, $\mu$ is the population mean, $T_{i}$ is the effect of the different silage (treatment effect) and ij is the random residual error

Table 1: Ingredients composition of the silages

\begin{tabular}{lllll}
\hline & \multicolumn{5}{c}{ Treatments } \\
\hline Ingredients & Control & USCT & BLSCT & UBLSCT \\
\hline Sugarcane top $(\mathrm{g})$ & 980 & 980 & 530 & 755 \\
Urea $(\mathrm{g})$ & - & 20 & - & 10 \\
Broiler litter $(\mathrm{g})$ & - & - & 450 & 225 \\
Molasses $(\mathrm{g})$ & 20 & 20 & 20 & 20 \\
Water $(\mathrm{ml})$ & 200 & 200 & 200 & 200 \\
\hline
\end{tabular}

USCT-urea treated sugarcane top silage, BLSCT- broiler litter treated sugarcane top silage, UBLSCTurea plus broiler litter treated sugarcane top silage

\section{Results}

The chemical composition of broiler litter and sugarcane top used for the study is presented in Table 2 . Broiler litter contained $89.14 \%, 20.32 \%, 38.87 \%$ and $26.28 \%$ dry matter, crude protein, $\mathrm{NDF}$ and $\mathrm{ADF}$, respectively while sugarcane top had $35.20 \%, 6.25 \%, 70 \%, 42.60 \%$ and $14.03 \%$ for the same parameters, respectively. Table 3 presented the chemical composition and $\mathrm{pH}$ of the sugarcane silages fed to the experimental animals.

Table 2: Chemical composition (\%) of concentrate, broiler litter and sugarcane top

\begin{tabular}{llll}
\hline Ingredients & Concentrates & Broiler litter & Sugarcane top \\
\hline Maize & 10.00 & - & - \\
Palm kernel cake & 25.00 & - & - \\
Groundnut cake & 5.00 & - & - \\
Wheat offal & 55.00 & - & - \\
Bone meal & 3.00 & - & - \\
Premix & 1.00 & - & - \\
Salt & 1.00 & - & - \\
Total & 100.00 & - & \\
Chemical composition (\%) & & & 35.20 \\
Dry matter & 88.03 & 89.14 & 6.25 \\
Crude protein & 15.41 & 20.32 & 8.00 \\
Ash & 5.50 & 20.00 & 3.00 \\
Ether extract & 4.00 & 2.00 & 70.00 \\
Neutral detergent fibre (NDF) & 320.00 & 38.87 & 42.60 \\
Acid detergent fibre (ADF) & 18.00 & 26.28 & 14.03 \\
Acid detergent lignin (ADL) & 8.00 & 15.26 & - \\
\hline
\end{tabular}


Akinbode, Isah, Oni, Adebayo, Aderinboye, Adelusi and Ojo

Table 3: Chemical composition (g/kg DM) and $\mathrm{pH}$ of sugarcane top silages fed to the West African dwarf sheep

\begin{tabular}{llllll}
\hline & \multicolumn{5}{c}{ Treatments } \\
\cline { 2 - 6 } Parameters & Control & USCT & BLSCT & UBLSCT & SEM \\
\hline pH & $3.80^{\mathrm{b}}$ & $4.33^{\mathrm{a}}$ & $4.50^{\mathrm{a}}$ & $4.47^{\mathrm{a}}$ & 0.14 \\
Dry matter & $301.20^{\mathrm{c}}$ & $287.57^{\mathrm{c}}$ & $400.80^{\mathrm{a}}$ & $320.00^{\mathrm{b}}$ & 13.37 \\
Crude protein & $86.00^{\mathrm{c}}$ & $120.00^{\mathrm{b}}$ & $133.10^{\mathrm{a}}$ & $122.60^{\mathrm{b}}$ & 5.44 \\
Ether extract & $21.20^{\mathrm{b}}$ & $20.00^{\mathrm{b}}$ & $35.00^{\mathrm{a}}$ & $25.00^{\mathrm{b}}$ & 1.96 \\
Ash & $75.00^{\mathrm{c}}$ & $90.00^{\mathrm{b}}$ & $130.00^{\mathrm{a}}$ & $95.00^{\mathrm{b}}$ & 6.16 \\
Neutral detergent fibre & $680.00^{\mathrm{a}}$ & $630.00^{\mathrm{bc}}$ & $610.00^{\mathrm{c}}$ & $650.00^{\mathrm{b}}$ & 8.36 \\
Acid detergent fibre & $380.00^{\mathrm{a}}$ & $362.50^{\mathrm{b}}$ & $350.00^{\mathrm{b}}$ & $355.00^{\mathrm{b}}$ & 3.97 \\
Acid detergent lignin & $120.00^{\mathrm{a}}$ & $110.00^{\mathrm{ab}}$ & $100.00^{\mathrm{b}}$ & $105.00^{\mathrm{b}}$ & 2.73 \\
Hemicellulose & $300.00^{\mathrm{a}}$ & $267.50^{\mathrm{b}}$ & $260.00^{\mathrm{b}}$ & $295.00^{\mathrm{a}}$ & 5.28 \\
Cellulose & $260.00^{\mathrm{a}}$ & $252.50^{\mathrm{ab}}$ & $250.00^{\mathrm{b}}$ & $250.00^{\mathrm{b}}$ & 1.68 \\
\hline
\end{tabular}

There were significant differences $(\mathrm{P}<$ $0.05)$ in all the parameters considered across the treatments with BLSCT having the highest values for $\mathrm{pH}$ (4.50), dry matter $(400.80 \mathrm{~g} / \mathrm{kg})$, crude protein $(133.10 \mathrm{~g} / \mathrm{kg}$ $\mathrm{DM})$, ether extract $(35.00 \mathrm{~g} / \mathrm{kg} \mathrm{DM})$ and ash $(130.00 \mathrm{~g} / \mathrm{kg} \mathrm{DM})$. USCT recorded lowest dry matter content $(287.57 \mathrm{~g} / \mathrm{kg})$ while the control silage had the least crude protein and ash contents $(86$ and $75 \mathrm{~g} / \mathrm{kg}$ respectively). NDF and $\mathrm{ADF}$ were significantly highest $(\mathrm{P}<0.05)$ in the control silage $(680.00$ and $380.00 \mathrm{~g} / \mathrm{kg})$ while USCT, BLSCT and UBLSCT had similar $(\mathrm{P}>0.05)$ ADF content.

Performance characteristics and apparent nutrient digestibility of West African dwarf sheep fed sugarcane top silage is shown in Table 4.

Table 4: Performance characteristics and apparent nutrient digestibility of West African dwarf sheep fed sugarcane top silage

\begin{tabular}{|c|c|c|c|c|c|}
\hline \multirow[b]{2}{*}{ Parameters } & \multicolumn{5}{|c|}{ Treatments } \\
\hline & Control & USCT & BLSCT & UBLSCT & SEM \\
\hline Initial weight $(\mathrm{kg})$ & 14.33 & 14.67 & 15.33 & 14.00 & 0.34 \\
\hline Final weight $(\mathrm{kg})$ & $16.10^{c}$ & $16.93^{\mathrm{b}}$ & $19.20^{\mathrm{a}}$ & $16.77^{\mathrm{b}}$ & 0.49 \\
\hline Total weight gain $(\mathrm{kg})$ & $1.77^{\mathrm{c}}$ & $2.27^{\mathrm{b}}$ & $3.87^{\mathrm{a}}$ & $2.77^{\mathrm{b}}$ & 0.26 \\
\hline Silage intake (g/day) & $230.15^{\mathrm{c}}$ & $229.35^{\mathrm{c}}$ & $342.08^{\mathrm{a}}$ & $270.76^{\mathrm{b}}$ & 13.87 \\
\hline Concentrate intake (g/day) & 201.88 & 202.47 & 201.88 & 201.00 & 0.39 \\
\hline Total dry matter intake (g/day) & $432.03^{c}$ & $431.82^{c}$ & $543.96^{\mathrm{a}}$ & $471.76^{\mathrm{b}}$ & 13.86 \\
\hline Total dry matter intake $\left(\mathrm{g} / \mathrm{kgW}^{0.75}\right)$ & $50.52^{c}$ & $54.78^{\mathrm{b}}$ & $64.26^{\mathrm{a}}$ & $60.83^{\mathrm{ab}}$ & 1.42 \\
\hline Feed conversion ratio & $20.62^{\mathrm{a}}$ & $16.52^{\mathrm{b}}$ & $12.05^{\mathrm{d}}$ & $14.34^{\mathrm{c}}$ & 1.10 \\
\hline \multicolumn{6}{|l|}{ Apparent nutrient digestibility (\%) } \\
\hline Dry matter & $55.71^{\mathrm{c}}$ & $60.60^{\mathrm{b}}$ & $71.43^{\mathrm{a}}$ & $62.93^{\mathrm{b}}$ & 1.78 \\
\hline Organic matter & $57.31^{\mathrm{c}}$ & $60.55^{\mathrm{bc}}$ & $71.16^{\mathrm{a}}$ & $63.41^{\mathrm{b}}$ & 1.64 \\
\hline Crude protein & $59.98^{c}$ & $69.39^{\mathrm{b}}$ & $75.66^{\mathrm{a}}$ & $71.55^{\mathrm{b}}$ & 1.83 \\
\hline Neutral detergent fibre & $39.47^{\mathrm{c}}$ & $47.80^{\mathrm{b}}$ & $64.35^{\mathrm{a}}$ & $50.21^{\mathrm{b}}$ & 2.76 \\
\hline Acid detergent fibre & $46.92^{\mathrm{b}}$ & $54.93^{\mathrm{a}}$ & $56.82^{\mathrm{a}}$ & $55.07^{\mathrm{a}}$ & 1.44 \\
\hline
\end{tabular}

The final weight, total weight gain, total dry matter intake were significantly highest $(\mathrm{P}$ $<0.05)$ in sheep fed BLSCT $(19.20 \mathrm{~kg}$, $3.87 \mathrm{~kg}$ and $64.26 \mathrm{~g} / \mathrm{kg} \mathrm{W}^{0.75}$ respectively) while sheep fed control silage recorded the least values $(16.10 \mathrm{~kg}, 1.77 \mathrm{~kg}$ and
$50.52 \mathrm{~g} / \mathrm{kg} \mathrm{W}^{0.75}$ ) Feed conversion ratio was highest in the control silage (20.62) and least in animals fed BLSCT silage (12.05). The dry matter, organic matter, crude protein and NDF digestibility were highest $(\mathrm{P}<0.05)$ in animals placed on BLSCT 
silage $(71.43 \%, 71.16 \%, 75.66 \%$ and $64.35 \%)$ and lowest in those on control silage $(55.71 \%, 57.31 \%, 59.98 \%$ and $39.47 \%$ ). Acid detergent fibre digestibility was similar $(\mathrm{P}>0.05)$ and higher in animals fed USCT (54.93\%), BLSCT (56.82\%) and
UBLSCT $(55.07 \%)$ but lowest $(\mathrm{P}<0.05)$ in those fed control silage (46.92\%).

Haematological and biochemical components of West African dwarf sheep fed sugarcane top silage is presented in Table 5.

Table 5: Haematological and biochemical components of West African dwarf sheep fed sugarcane top silage

\begin{tabular}{llllll}
\hline & \multicolumn{5}{c}{ Treatments } \\
\cline { 2 - 6 } Parameters & Control & USCT & BLSCT & UBLSCT & SEM \\
\hline Packed cell volume (\%) & $27.00^{\mathrm{b}}$ & $28.33^{\mathrm{b}}$ & $32.17^{\mathrm{a}}$ & $27.83^{\mathrm{b}}$ & 0.43 \\
Haemoglobin (g/dL) & $7.80^{\mathrm{c}}$ & $9.30^{\mathrm{b}}$ & $10.82^{\mathrm{a}}$ & $9.02^{\mathrm{b}}$ & 0.13 \\
Red blood cells (x10 $\left.{ }^{12} / \mathrm{L}\right)$ & $10.07^{\mathrm{c}}$ & $11.98^{\mathrm{b}}$ & $13.43^{\mathrm{a}}$ & $11.78^{\mathrm{b}}$ & 0.17 \\
White blood cells (x10\%/L) & 9.37 & 8.55 & 9.12 & 9.20 & 0.40 \\
MCV (fL) & 23.80 & 23.60 & 23.90 & 23.60 & 0.12 \\
MCH (fmol) & 7.83 & 7.79 & 8.12 & 7.66 & 0.60 \\
MCHC (\%) & 29.98 & 33.00 & 34.00 & 32.40 & 0.17 \\
Lymphocyte (\%) & 51.00 & 49.00 & 50.83 & 49.50 & 1.14 \\
Neutrophil (\%) & 45.17 & 47.00 & 46.00 & 46.00 & 2.06 \\
Basophil (\%) & 0.00 & 0.00 & 0.00 & 0.00 & 0.00 \\
Eosinophil (\%) & $3.33^{\mathrm{b}}$ & $3.50^{\mathrm{a}}$ & $3.30^{\mathrm{b}}$ & $3.67^{\mathrm{a}}$ & 0.11 \\
Monocyte (\%) & 0.50 & 0.50 & 0.50 & 0.83 & 0.09 \\
Biochemical components & & & & & \\
Glucose (mmol/L) & $2.85^{\mathrm{b}}$ & $3.83^{\mathrm{a}}$ & $3.94^{\mathrm{a}}$ & $3.75^{\mathrm{a}}$ & 0.13 \\
Total protein (g/L) & $53.3^{\mathrm{b}}$ & $71.5^{\mathrm{a}}$ & $71.8^{\mathrm{a}}$ & $71.2^{\mathrm{a}}$ & 1.53 \\
Albumin (g/L) & $30.0^{\mathrm{b}}$ & $35.0^{\mathrm{a}}$ & $37.0^{\mathrm{a}}$ & $34.5^{\mathrm{a}}$ & 0.06 \\
Globulin (g/L) & $23.3^{\mathrm{b}}$ & $36.5^{\mathrm{a}}$ & $34.8^{\mathrm{a}}$ & $36.7^{\mathrm{a}}$ & 1.45 \\
Urea nitrogen (mg/L) & $70.90^{\mathrm{b}}$ & $140.65^{\mathrm{a}}$ & $130.55^{\mathrm{a}}$ & $120.90^{\mathrm{a}}$ & 0.20 \\
Creatinine (mg/dl) & 6.00 & 6.20 & 6.50 & 6.50 & 0.12 \\
\hline
\end{tabular}

$\overline{a, b, c}$ Means on the same row having different superscripts are significantly different $(P<0.05)$, SEM-Standard error of mean, USCT-urea treated sugarcane top silage, BLSCT-broiler litter treated sugarcane top silage, UBLSCT-urea plus broiler litter treated sugarcane top silage

There were significant differences $(\mathrm{P}<$ $0.05)$ in the packed cell volume (PCV), haemoglobin $(\mathrm{Hb})$ and red blood cells (RBC) concentration of the animals across the treatments. Animals fed BLSCT silage recorded highest values for packed cell volume, haemoglobin and red blood cell concentration $(32.17 \%, 10.82 \mathrm{~g} / \mathrm{dL}$ and $13.43 \mathrm{~L}^{-1}$, respectively) while those on control silage had the least haemoglobin and red blood cell concentration $(7.80 \mathrm{~g} / \mathrm{dL}$ and $\left.10.07 \mathrm{~L}^{-1}\right)$. Packed cell volume concentration was similar $(\mathrm{P}>0.05)$ in animals placed on control, USCT, and UBLSCT silages. No significant difference $(\mathrm{P}>0.05)$ was observed in white blood cells, lymphocyte, Neutrophil, Basophil, Eosinophil and monocyte concentrations of the animals across the treatments.

There were significant differences $(\mathrm{P}<$ $0.05)$ in all the biochemical components considered across the treatments except creatinine concentration which was not significant $(\mathrm{P}>0.05)$. Animals fed USCT $(3.83 \mathrm{mmol} / \mathrm{L}, 71.50 \mathrm{~g} / \mathrm{L}, 35.0 \mathrm{~g} / \mathrm{L}, 36.50$ $\mathrm{g} / \mathrm{L}$ and $140.65 \mathrm{mg} / \mathrm{L})$, BLSCT $(3.94$ $\mathrm{mmol} / \mathrm{L}, 71.80 \mathrm{~g} / \mathrm{L}, 37.00 \mathrm{~g} / \mathrm{L}, 34.80 \mathrm{~g} / \mathrm{L}$ and $130.55 \mathrm{mg} / \mathrm{L})$ and UBLSCT $(3.75$ $\mathrm{mmol} / \mathrm{L}, 71.20 \mathrm{~g} / \mathrm{L}, 34.50 \mathrm{~g} / \mathrm{L}, 36.70 \mathrm{~g} / \mathrm{L}$ and $120.90 \mathrm{mg} / \mathrm{L})$ recorded similar $(\mathrm{P}>$ 0.05 ) and higher concentration for glucose, total protein, albumin, globulin and urea 


\section{Akinbode, Isah, Oni, Adebayo, Aderinboye, Adelusi and Ojo}

nitrogen concentration respectively while those on control silage had the least values $(2.85 \mathrm{mmol} / \mathrm{L}, 53.30 \mathrm{~g} / \mathrm{L}, 30.00 \mathrm{~g} / \mathrm{L}, 23.30$ $\mathrm{g} / \mathrm{L}$ and $70.90 \mathrm{mg} / \mathrm{L}$ )

\section{Discussion}

The crude protein $(\mathrm{CP})$, neutral detergent fibre (NDF) and acid detergent fibre (ADF) contents of sugarcane top (SCT) used in this study were comparable to that reported by previous authors (Kumarmath et al., 2004; Chaudhry and Naseer, 2008). However, the recorded crude protein content of sugarcane top was lower than $8 \%$ crude protein required to satisfy the maintenance of ruminants as reported by Norton (2003), therefore, supplementation will be required when SCT is to be fed to small ruminant in Nigeria. The nutrient contents of broiler litter (BL) used was similar to the value reported by Ososanya et al. (2007) and lower than that reported by other author (Chaudhry and Naseer, 2012). The observed variations in the nutrient composition of BL in this study as compared with previous studies might be due to the type of feed consumed by birds, degree of contamination of excreta with bedding, type of bedding materials used and the processing techniques adopted (Owen et al., 2008). The $\mathrm{pH}$ of all treated silages in the current study increased with addition of urea and broiler litter when compared with the control. Berger et al. (1994) explained that buffer capacity of silages increased with addition of nonprotein nitrogen (NPN) substance which resulted in increased $\mathrm{pH}$ of silage. However, the $\mathrm{pH}$ range observed was within the limit of good silage $\mathrm{pH}$ as reported by MCDonald (1981).

The chemical composition silages fed to WAD sheep revealed highest DM content of BLSCT silage compared with other treatments which might be as a result of high DM content of broiler litter used. This also reflected in the UBLSCT silage which contained higher DM content than both the control silage and USCT silage. Highest crude protein content recorded in BLSCT followed by UBLSCT and USCT silage could be as a result of NPN (broiler litter and urea) added to these silages. The reduction of NDF, ADF and ADL in USCT, BLSCT and UBLSCT could be attributed to the ability of urea and broiler litter to produce ammonia during ensiling which helped to breakdown the lignin walls. It is of interest to note that the NDF content of all the silages produced except that of control were within $650 \mathrm{~g} / \mathrm{kg} \mathrm{DM}$ suggested as the limit above which the intake of tropical feeds by ruminant animals would be limited (Van Soest, 1994).

The average daily weight gain of sheep recorded across the treatments in this study was higher than those reported by Malisetty et al. (2013) when maize silage supplemented with concentrate and legume hay was fed to Nellore ram lambs and lower than that reported by Vidya et al. (2012) for native sheep fed sweet sorghum bagasse leaf residue silage (SSBLR) supplemented with 225 and $280 \mathrm{~g}$ of concentrate feed, respectively. The highest total weight gain recorded in sheep fed BLSCT silage might be as a result of highest crude protein content of this silage and also due to their high dry matter intake. Protein intake has been reported as a major determinant of ruminant performance as it increased the availability of fermentable nitrogen required by rumen microbes and also increases the chance of rumen by-pass protein (Yusuf, 2011). The low dry matter intake recorded in sheep fed USCT silage might be as a result of pungent smell observed in this silage. Lower feed conversion ratio obtained in sheep fed BLSCT silage indicated better performance which means that necessary nutrients (especially fermentable nitrogen) had been supplied in ensuring optimum 
microbial biomass and this agreed with earlier report by Leng (1990) that adequate nutrients in feeds taken by ruminants would stimulate optimal production in ruminant livestock.

High digestibility of nutrients recorded in animals fed BLSCT was in agreement with the findings of Ørskov (1986) who showed that supplementation with poultry litter enhanced the digestibility of poor quality crop residues by supplying needed ammonia required by the rumen microbes.

Blood is a good indicator to monitor the health of an organism (Joshi et al., 2002) and ingestion of various dietary components has been reported to have measurable effects on blood constituents of various animals (Arowora et al., 2003). The mean values of packed cell volume (PCV) recorded across the treatments at the end of the experiment fell within the range of $24-$ $48 \%$ reported for clinically healthy goats (Banerjee, 2004). Haemoglobin concentration $(\mathrm{Hb})$ and red blood cell counts followed the same trend as in PCV and the values recorded across the treatments for $\mathrm{Hb}$ were higher than $5-6$ $\mathrm{g} / \mathrm{dL}$ reported by Belewu and Ogunsola (2010) but were within the range of $7-15$ $\mathrm{g} / \mathrm{dL}$ stated for WAD goats by Daramola $e t$ al. (2005). As for RBC, Bello and Tsado (2013) reported values ranging from $6.4-$ $9.9 \times 10^{12} / \mathrm{L}$ when growing Yankassa rams were fed sorghum stover supplemented with graded level of dried poultry droppings, however, these values were lower than that obtained in this study. Values obtained in this study indicated that dietary protein of the silages were of high quality since Adeyemi et al. (2008) observed that red blood cell and haemoglobin were positively correlated with protein quality and protein level in the diets. Mean corpuscular volume (MCV), mean corpuscular haemoglobin $(\mathrm{MCH})$ and mean corpuscular haemoglobin concentration (MCHC) are important diagnosis of anaemia in most animals (Coles, 1986) and values obtained were within the normal ranges $(16-25 \mathrm{fL}, 5-8$ fmol and $28-34 \%$ for MCV, MCH and MCHC, respectively) (Sirois, 1995). This indicated that all the experimental animals used were not anaemic at the end of the experiment. Values recorded for white blood cell (WBC), lymphocyte and eosinophil counts were within the ranges reported for healthy goats (Sirois, 1995) and this is an important indication of the health status of the experimental animals. Lymphocytes are essential for humoral and cell- mediated immunity responses and monocytes are essential for the immunity system as they are precursors of macrophages (Mahgoub et al., 2008). Lack of basophil at the end of the experiment was an indication of disease free condition by the experimental animals as reported by Cole (1986). The range of blood glucose obtained in sheep fed USCT, BLSCT and UBLSCT were similar to the values reported by Mavimbela et al. (1997) when high broiler diets were fed to sheep as survival ration. Blood glucose had been used to monitor the nutrient status in animals (Turner et al., 2005) and animal performance such as weight gain depends on it (Lazzaro, 2001). This also reflected in the weight gain of the animals recorded in this study as sheep placed on BLSCT silage with highest blood glucose had the highest weight gain.

The serum protein concentration indicates the balance between anabolism and catabolism in the body. However, the range of serum protein obtained in animals fed USCT, BLSCT and UBLSCT in the present study was within the normal range of 6 $7.90 \mathrm{~g} / \mathrm{dL}$ reported by Kaneko (1980). This implied that the test diets were able to supply adequate amount of protein needed to maintain normal sesrum protein level. The serum albumin values in this study agreed with the report of Cole (1986). The 
higher concentration of serum albumin observed in animals on USCT, BLSCT and UBLSCT may be due to the higher digestibility of crude protein observed in these silages when compared with that of control silage. The serum urea concentration is closely associated with the breakdown and de-amination of protein in the rumen and the rate of ammonia utilization for bacterial protein synthesis. According to Kaneko (1980), an increase in the serum urea level may reflect an accelerated catabolism rather than a decrease in urinary excretion. The higher concentration of serum urea in all treatments except control silage was in line with the findings of Dass et al. (1996) who reported that, supplementation of the basal diet of buffaloes with non-protein nitrogen compounds resulted in higher serum urea concentrations. However, the values fall within the normal range of $80-200 \mathrm{mg} / \mathrm{L}$ (Kaneko, 1980) and implied that supplementation with non-protein nitrogen source had positive effect on blood urea concentration.

\section{Conclusion}

Sugarcane top treated with urea, broiler litter or their combination improved the performance, digestibility and also gave normal haematological and serum metabolites of West African dwarf sheep. It is therefore concluded that sugarcane top treated with $2 \%$ urea or $45 \%$ broiler litter or their combination ensiled for 42 days can be fed to ruminants during the dry season without any detrimental effect on the animals.

\section{References}

Adeyemi, O. A., Eruvbetine, D., Oguntona, T., Dipeolu, M. A and Agunbiade, J. A. 2008. Feeding broiler chicken with diets containing whole cassava root meal fermented with rumen filtrate.
Archivos de Zootechnia , 57: 247258

Akinmutimi, A. H. 2004. Evaluation of sword bean Canavalia gladiata as an alternatiave

feed resource for broiler chickens. Ph.D. Thesis, Michael Okpara Univesity of Agriculture Umudike, Nigeria.

AOAC. 2005. Official Methods of Analysis. 15th ed. Association of Official Analytical Chemists, Washington, DC.

Arowora, K. A. Onilude, A. A. and Tewe, O. O. 2003. Seral, haematological and economies of production of weaner pigs fed graded levels of bio degraded cassava (Manihot esculenta) peels. Tropical Journal of Animal Science, 6: 7-16.

Banerjee, G. C. 2004. A text book of Animal Husbandry. 8th ed. Oxford and IBH Publishing Co. PVT, LTD, New Delhi.

Belewu, M. A. and Ogunsola, F. O. 2010. Haematology and serum indices of Goat fed fungi treated and untreated Jatropha curcas kernel cake in a mixed ration. Journal of Agriculture, Biology and Sustainable Development, 2 (3): 35-38.

Bello, A. A. and Tsado, D. N. 2013. Feed intake and nutrient digestibility of growing Yankasa rams fed sorghum stover supplemented with graded levels of dried poultry droppings based diet. Asian Journal of Animal Sciences, 7: 5663.

Berger, L. L., Fahey, G. C., Bourguin, L. D. and Titgemeyer, E. C. 1994. Modification of forage quality after harvest In: George, C. and Fahey, J.R. (Ed.) Forage Quality Evaluation and Utilization, American Society of Agronomy Inc., Lincoln. 
Bhatti, M. B. and Khan, S. 1996. Fodder Production in Pakistan. FAO PARC, Islamabad.

Chaudhry, S. M. and Naseer, Z. 2008. Safety of ensiling poultry litter with sugarcane top. Pakistan Journal of Agricultural Science, 45(2): 322-326.

Chaudhry, S. M. and Naseer, Z. 2012. Processing and nutritional value of broiler litter as a f e e d for buffalo steers, The Journal of Animals and Plant Sciences, 22(3): 358-364

Coles, E. H. 1986. Veterinary Clinical Pathology, 4th ed. W.B. Saunders Co., Philadelphia, PA, USA, pp. 486.

Dacie, J. V. and Lewis, S. M. 2001. Practical haematology $9^{\text {th }}$ ed. Churchhill Livingstone, London, pp.633.

Daramola, J. O., Adeloye, A. A, Fatoba, T. A. and Soladoye, A. O. 2005. Haematological and Biochemical parameters of WAD goats. Livestock Research for Rural Development, 17: www. Cipav.org.co/lrrd.

Dass, R. S, Verma, A. K. and Mehra, U.R. 1996. Effect of feeding urea molasses liquid diet on nutrient utilization, rumen fermentation pattern and blood profile in adult male buffaloes. Buffalo Journal, 12: 11-22.

Fang, J. M., Matsuzaki, H., Suzuki, Y., Cai, K., Horiguchi, Takahashi, $T$. 2012. Effects

of lactic acid bacteria and urea treatment on fermentation quality, digestibility and ruminal fermentation of roll bale rice straw silage in wethers. Grassland Science, 58: 73-78.

Food and Agriculture Organization, 1980. Integration of crops and livestock in West
Africa. FAO Animal production and Health paper 41, Rome.

Jain, N. C. 1993. Essentials of Veterinary Haematology. Lea and Ferbeiger, Pennsylvania, U.S.A. pp 7.

Joshi, A. L., Rangnekar, D. V., Mahendra, S., Kander, S. S., Ambedkar, S. R. and Bendigeri, A. V. 1995. Sugarcane Tops: Feeding of Ruminants on Fibrous Crop Residues. Hand Book of Straw Feeding System. Indian Council of Agric. Res., New Delhi, India, 343-405.

Joshi, P. K. Harish, D. and Bose M. 2002. Effect of lindane and malathione exposure to certain blood parameters in a fresh water teleost fish Clarias batrachus. Pollution Resource, 21: 55-57.

Kaneko, J. J. 1980. Clinical biochemistry of domestic animals. Academic Press Inc, Orlando, Florida.

Kim, S. C, Kim, J. H, Kim, C. H, Lee, J. C. and Ko, Y. D. 2000. Effects of whole crop corn ensiled with cage layer manure on nutritional quality and microbial protein synthesis in sheep. Asian Australian Journal of Animal Science, 13: 1548-1553.

Kumarmath, P. S., Renuka, C. K., Kadakoland, J. C. and Hosamani, S. V. 2004. Analysis of quality and anti-quality factors in locally available feeds and fodders. Karnataka Journal of Agricultural Science, 17(4): 794-798.

Lazzaro, J. 2001. Normal blood chemical values for adult goats. Available $\mathrm{f} \quad \mathrm{r} \quad \mathrm{o} \quad \mathrm{m} \quad$ : www.saanendoah.com/blood values.htmL.

Mahgoub, O., Kadim, I. T., Tageldin, M. H., Al-Marzooqi, W. S., Khalaf, S. Q. and Ali, A. A. 2008. Clinical profile of sheep fed non- 
Akinbode, Isah, Oni, Adebayo, Aderinboye, Adelusi and Ojo

convectional feeds containinig phenols and condensed tannins. Small Ruminant Resource, 78: 115122

Malisetty, V., Yerradoddi, R. R., Devanabiona, N., Mallam, M., Cherala, H. K. and Manthani, P. 2013. Effect of feeding maize silage supplemented with concentrate and

legume hay on growth in Nellore ram lambs. Veterinary world, 6(4): 209-213

Leng, R. A. 1990. Factors affecting the utilization of poor-quality forages by ruminants particularly under tropical conditions. Nutrition Research Reviews, 3: 277-303

Mavimbela, D. T., Van Ryssen, J. B. J. and Last, R. 1997. The effect of high broiler litter

diets as survival ration on the health of sheep. Journal of the South African Veterinary Association 68(4): 121-124 (En.). Department of Animal Science and Poultry Science, University of Natal, Pietermaritzburg, 3209 South Africa.

McDonald, P., Henderson, A. R. and Heron, S. J. E. 1991. The Biochemistry of Silage. Chalcombe Publications, Marlow, Buckinghamshire, UK, pp. 109.

Norton, B. W. 2003. Tree legumes and Dietary supplements. In: Forages Tree legumes in Tropical Agriculture, Gutteridge, R.C. and H.M Shelton, (Eds) CAB International, Wallingford, Oxon, 192-201

Ososanya, T. O., Odedire, J. A. and Oye yе mi, M. O. 2007 . Performance assessment of pregnant ewes fed broiler litter as feed supplement, Pakistan Journal of Nutrition, 6(6): 701-704.
Owen, O. J., Ngodigha, E. M. and Amakiri A. O. 2008. Proximate composition of heat treated poultry litter (Layers). International Journal of Poultry Science. 7(11): 1033-1035.

Ørskov, E. R., 1986. Starch digestion and utilization in ruminants. Journal of Animal Science, 63: 1624-1633.

Patil, N. V., Kharadi, V. B., Desai, P. M. and Desai, B. M., 1999. Comparative nutritional value of fresh and sun dried sugarcane tops in buffalo calves. Indian Journal of Animal Nutrition, 16: 259-261.

SAS, 1999. User's Guide: Statistics, Version 5 Edition. SAS. Inst. Cary, NC.

Shah, S. I. and Muller Z. O. 1983. Feeding animal wastes to ruminants. In: Byproduct utilization for animal production. Proceedings of a workshop on applied research held in Nairobi, Kenya, 26 - 30th September, 1982. IDRC, Ottawa, Canada, 49-57.

Sirois M, 1995. Veterinary Clinical Laboratory Procedure. Mosby Year Book, Inc. St Louis. Missouri, USA.

Turner, K. E., Wildeus, S. and Collins, J. R. 2005. Intake, performance and blood parameters in young goats offered high forage diets of Lespedeza or Alfalfa hay. Small Ruminant Research, 59(1): 15-23

Valley, H., Gowelock, A. H. and Bell, M., 1980. Determination of serum urea using diacetylmonoxime method. In: Practical Clinical Biochemistry, $5^{\text {th }}$ ed. William Heinemann Medical Book Ltd., London

Van Soest, P. J., Robertson, Lewis, B. A. 1991. Methods for dietary fibre and non-starch polysaccharides in relation to Animal Nutrition. Journal of Dairy Science. 74: 
Nutrient digestibility and blood parameters of West African dwarf sheep fed sugarcane top silage

3583-3597.

Van Soest, P. J. 1994. Nutritional Ecology of the Ruminant. $2^{\text {nd }}$ edition. Ithaca, New York: Cornell University Press.

Wermer, W. H., Rey, H. G. and Weielinger, H. 1970. Method of plasma glucose determination. Journal of Analytical Chemistry, 252: $224-228$
Yusuf, K. O. 2011. Effects of enzyme additive and in vitro parameters and utilization of fresh grass and grass hay-based diets by yearling calves. Ph.D thesis Department of Animal Nutrition, Federal University of Agriculture, Abeokuta, Nigeria.

Received: $14^{\text {th }}$ November, 2017

Accepted: $2^{\text {nd }}$ March, 2018 